Article

\title{
The Nourishing Sea: Partnered Guardianship of Fishery and Seabed Mineral Resources for the Economic Viability of Small Pacific Island Nations
}

\author{
Paul D'Arcy \\ Department of Pacific and Asian History, College of Asia and the Pacific, Australian National \\ University, Canberra, ACT 0200, Australia; E-Mail: paul.darcy@anu.edu.au
}

Received: 14 May 2013; in revised form: 3 July 2013 / Accepted: 12 July 2013 /

Published: 6 August 2013

\begin{abstract}
While island biogeography and modern economics portray Pacific island nations as isolated, ecologically fragile, resource poor and barely viable economies forever dependent on foreign aid, Pacific island history and culture conceives of their islands as intimately inter-linked to the surrounding ocean and of that ocean as an avenue to expanded resource bases, both terrestrial and aquatic. Pacific Islanders live in the most aquatic human zone on Earth, with the highest territorial ratios of sea to land. Recent studies are revealing the continuity and success of traditional near-shore guardianship of maritime resources in a number of Pacific islands. Sustainable development of seabed minerals and pelagic fisheries may offer enhanced income potential for small island nations with limited terrestrial resources. As offshore ecosystems are poorly policed, sustainable development is best realized through comprehensive planning centred on partnerships between local communities, their governments, marine scientists and commercial enterprises. The success or failure of Pacific Islanders in reasserting their maritime guardianship is now a matter of global significance given the decimation of most fisheries beyond the Pacific and the vast, but uncertain, medicinal, mineral and food resource potential of this huge area of the planet.
\end{abstract}

Keywords: Pacific islands; marine resources; seabed minerals; sustainable fisheries; partnerships 


\section{Introduction}

Satellite images of the Earth centered on the Pacific Ocean reveal a predominantly blue, aquatic planet. Most of this Pacific-centered hemisphere is taken up by the Pacific Ocean, with the continental boundaries of Asia, the Americas and Antarctica relegated to the margins. Unpopulated or under-populated, with small island human communities only, the Pacific Ocean, and its high seas, in particular, have become regarded as a common resource for all, controlled only by voluntary adherence to general international principles of conduct, because they lie beyond the monitoring capacity of almost all nation states and international bodies. The term high seas refer specifically to seas beyond the Exclusive Economic Zones (EEZ) of nation states under the United Nations Convention on the Law of the Sea (UNCLOS). The last decade has revealed mounting scientific evidence that this regime is not working, as once prolific fisheries decline substantially and much of the northern Pacific is covered in two huge gyres of floating, non-biodegradable garbage. The global problem of climate change also affects the Pacific dramatically, especially with rising sea levels threatening the viability of many atoll nations and causing severe biological stress on coral reef ecosystems.

This ocean degradation poses particular problems for many of the archipelagic nations of the Pacific, which are overwhelmingly coralline and aquatic and derive much of their national income from larger, wealthier Pacific Rim nations' payments of access fees to exploit their fisheries and, soon, perhaps their seabed minerals. The term Pacific Rim nations collectively refers to nations straddling the Asian and American continental borders of the Pacific Ocean (China, Taiwan, Japan, South Korea, North Korea, Russia, USA, Mexico, Guatemala, El Salvador, Nicaragua, Costa Rica, Panama, Colombia Ecuador, Peru and Chile), as well as the Island Southeast Asian nations of Indonesia and the Philippines and, finally, Australia. Pacific island nations are reasserting their ancient guardianship of the sea within this new worrying scenario in which they have been marginalized for too long. While island biogeography and modern economics portray such island nations as isolated, ecologically fragile, resource poor and barely viable economies forever dependent on foreign aid, Pacific island history and culture conceives of their islands as intimately inter-linked to the surrounding ocean and of that ocean as an avenue to expanded resource bases, both terrestrial and aquatic. Pacific Islanders live in the most aquatic human zone on Earth with the highest territorial ratios of sea to land. Recent studies are revealing the continuity and success of traditional guardianship of maritime resources in a number of Pacific islands. The success or failure of Pacific Islanders in reasserting their maritime guardianship is now a matter of global significance given the decimation of most fisheries beyond the Pacific and the undetermined medicinal, mineral and food resource potential of this huge surface of the planet and the vast volume of water beneath it.

\section{Economic Viability and Sustainable Development in Oceania}

Pacific island nations receive significant aid from their former colonial rulers, but this aid is increasingly coming with conditions attached and the ever-present threat of imminent reduction. With high birth rates, aid has already effectively diminished per head of population. Pacific territories that are still part of the territory of former colonial powers generally benefit from significant metropolitan funding, so that their income is often greater than that of their independent neighbours per head of population [1]. The result has been that the current generation of Pacific Islanders has 
witnessed an unprecedented harvesting of terrestrial minerals, forest resources and offshore fisheries. Many of the archipelagic nations of Oceania are overwhelmingly coralline and aquatic and derive much of their national income from resource rents paid by fleets from Pacific Rim nations to fish this huge ocean surface of the planet and the vast volume of water beneath it. European nations have also signalled increasing interest in access to Pacific fisheries, although negotiations are currently deadlocked [2]. France plays an important role in Pacific marine research and conservation within and beyond its Pacific overseas' territories. Seabed mining offers a potential supplementary income source or, perhaps, a viable alternative to dependence on aid monies and stressed or exhausted land-based minerals, timber and near-shore and off-shore fisheries. The potential benefits are significant, while the potential consequences are uncertain.

Fears of economic viability as micro-economies in a global world and political coherence as arbitrary colonial boundaries united diverse peoples delayed independence until the mid- to late 1970s for most Pacific nations. Independent Pacific island states vary considerably in size from ten thousand in Tuvalu to approximately six million, one-hundred thousand in Papua New Guinea (PNG). A variety of languages are spoken within each nation state, and the kin-based identity is the dominant affiliation of most citizens. Most inherited limited infrastructure from their colonial rulers, since independence has been unable to provide the transport, educational, health and economic facilities needed to make their citizens willing and able to operate as citizens of a modern state. Most people still practice essentially highly localized subsistence lifestyles occasionally supplemented by cash crops. Despite poor communications and, at times, tense relations between social groups, a sizable minority of the population now travel beyond their kin group area to work in the modern economy, especially in national capitals or large multinational undertakings, such as mine sites. Such gathering places are sources of both identity formation and tension. While a new class-based urban identity has begun to take place in cities, such as Suva, many, if not most, migrants to cities rely upon wantoks - networks who speak the same language and share cultural origins [3].

The dominant development paradigm since independence has been the so-called MIRAB economy, used to describe many of the smaller nations of contemporary Oceania. The term MIRAB refers to the main funding sources of these economies; migration, remittances, aid and bureaucracy. The MIRAB image is one of tiny, non-viable economies forever condemned to dependency on aid from former colonial powers, as most aid is absorbed in civil service salaries, so that remittances dependent on variable access to Pacific Rim labour markets become the main income source for those outside of government $[4,5]$. The late Tongan scholar, Epeli Hau'ofa, argues that these MIRAB "basket cases" were the result of barriers created by colonial boundaries and policies that imposed an artificial sense of isolation and separation upon islanders. They must now de-colonise their minds, and recast their sense of identity by rediscovering the vision of their ancestors for whom the Pacific was a boundless sea of possibilities and opportunities [6]. Most MIRAB economies fall within the conventional divisions of Polynesia and Micronesia and consist of relatively small, crowded islands in regions where sea spaces dominate and form the majority of the region's surface. Fisheries are an important resource for many of these nations, but access to the labour markets of former colonial rulers on the Pacific Rim are also important and possible because of the relatively small size of these national populations compared to the largest Pacific nations in Melanesia in the southwest Pacific. The term Melanesia (dark islands) was originally coined by early explorers in reference to a Pacific island sub-region 
populated by what was perceived to be a separate race of culturally distinct, dark-skinned Pacific Islanders as opposed to lighter skinned inhabitants in the other two Pacific island sub-regions of Micronesia (small islands) and Polynesia (many islands). These cultural and ethnic classifications have largely been discredited today, although Melanesia remains a useful classification for distinguishing its constituent political entities of PNG, the Solomon Islands, Vanuatu and New Caledonia as larger islands of the southwest Pacific islands with greater terrestrial resources and larger populations than the smaller, less well-resourced islands of Micronesia to the north and Polynesia to the east [7].

The resource rich and larger Pacific nations of Melanesia, especially PNG and the Solomon Islands, display a different economic pattern of large-scale and foreign controlled multinational companies extracting minerals, timber and fish and exporting them largely unprocessed, so that host nations develop comparatively few ancillary and value-added industries and receive only a fraction of the potential value of their raw materials. Melanesian nations' large populations have deterred Pacific Rim nations from legislating for enduring access to their labour markets, adding further pressure to develop domestic primary industries based on the extraction of raw materials. Limited resources for environmental policing of resource extraction sites, the political marginalization of land owners in the immediate vicinity of these operations, because of their small numbers and, therefore, limited parliamentary representation, and the large percentage of national income gathered by governments from multinationals have given rise to the resource curse paradigm, where resources are considered at best a double-edged sword. They attract outsiders with no commitment to local sustainability and divide local communities, pitting these same communities against what is often perceived of as an unholy alliance between big business and national governments [8-14]. Resource rich areas are often lightly populated, leading to the tragedy of the commons scenarios in which resources owned by no one are protected and sustained by no one, especially away from national capitals, where they are designated terra nugax (land belonging to no one) by authorities and become a sort of unclaimed frontier ripe for harvesting, because of the limited voting power of locals [15].

\section{International Legal Rights and Economic Realities in Pacific Island Maritime Economies}

The 1982 United Nations Convention on the Law of the Sea (UNCLOS III) forms the basis of ocean governance in Oceania. The Convention substantially extended coastal nations' sovereignty over adjacent waters [16-18] This benefited most modern Pacific nations as island archipelagos surrounded by vast expanses of ocean. The outer limit of territorial seas was set at 12 nautical miles $(22 \mathrm{~km})$, but coastal states' sovereignty over the living and non-living marine resources was extended to 200 nautical miles $(370.4 \mathrm{~km})$ from shore in the form of Exclusive Economic Zones (EEZs). Coastal states were also given the right to designate what constituted a sustainable catch within their EEZ, as well as who would get access to harvesting stock in excess of this sustainable catch and the fee they would pay to the coastal state in return for this access [16] (Articles 55-75, especially 55-59). Coastal states were also given rights over the seabed and its subsoil on continental shelves. These are relatively shallow seas that extend out unbroken from the coast. Because of variable geological criteria, they were given fixed legal definitions relating to distance from shore and depth: extending to 350 nautical miles $(648 \mathrm{~km})$ from defined coastlines or 100 nautical miles $(185.2 \mathrm{~km})$ beyond the 2,600 meter isobeth [16] (Articles 76-85). (An isobeth is a conceptual line joining points of the same depth.) 
UNCLOS III also provided a detailed conflict resolution structure to resolve competing claims, such as where EEZs and continental shelves overlapped, for example. Beyond these sovereign areas, the principle of freedom of the high seas prevailed, with access open to all. However, even here, regulation designed to avoid conflict has occurred. For example, the International Seabed Authority has recognized and registered claims made on much of the eastern Pacific seabed by various applicant nations or national commercial entities, because of the potential wealth of seabed minerals there, despite most of this region lying in international waters beyond any EEZ [19]. As discussed below, however, these resources have recently been found to be extremely valuable, to the point where they are commercially viable to mine with currently available technology, yet they lie in maritime regions still only governed by voluntary adherence to vague principles, rather than set laws and effective monitoring and enforcement mechanisms.

The last legal concept used in UNCLOS III for extending coastal sovereignty was that of archipelagic rights. Nations with islands considered so closely linked politically, geographically and historically as to form an intrinsically inter-linked entity were given the right to draw their EEZ baseline around the outer edge of their outer islands. All waters within this baseline are deemed to be territorial waters, as long as the ratio of water to land is not greater than nine to one [16] (Articles 46-54, especially 47-50), [20].

UNCLOS III did not officially come into force until 1994, when the required number of nations had ratified it. By then, Pacific island nations had introduced national legislation to apply its measures within their national boundaries, and the provisions were operating de facto in international fishing agreements relating to the Pacific. The new 200 miles $(370.4 \mathrm{~km})$ EEZs dramatically increased the territory of Pacific island nations, particularly archipelagic ones. For example, Fiji's 18,272 square kilometre of land provided an EEZ of 1,290,000 square kilometre, Kiribati's 690 square kilometre of islands translated into an EEZ of 3,550,000 square kilometre, while the Federated States of Micronesia's (FSM) 701 square kilometre of land equated to an EEZ of 2,978,000 square kilometre. Kiribati derives $45 \%$ of its revenue from fishing and fishing license fees, while the Federated States of Micronesia derive around a quarter of its revenue from these sources. The largest EEZ in Oceania is that of French Polynesia, whose 4,167 square kilometre of land resulted in an EEZ of 4,767,242 square kilometre [3] (p. 369), [20-23].

The potential maritime benefits of political independence have been eroded by economic realities. As small or fragmented political and cultural entities that inherited limited modern infrastructure from their former colonial rulers, Pacific island nations had limited ability to generate income domestically; this meant that much income was absorbed in providing basic facilities and services taken for granted in more developed nations. Offshore fishing fleets from larger and wealthier Pacific Rim nations regularly violated Pacific island EEZs in the absence of local monitoring. The same lack of resources to monitor offshore waters also meant that Island nations could not develop effective fishing fleets and were forced into fishing access agreements that returned a mere fraction of the value of the catch at market. The alternatives were forgoing this income and watching the offshore fishery erode through unmonitored fishing by non-citizens or continued over-reliance on foreign aid from former colonizers [3] (pp. 368, 377-378), [24] (p. 83), [25-28].

Conditions improved as island nations agreed to speak as one through the Forum Fisheries Agency, which developed considerable scientific and legal expertise on Pacific fisheries management. 
Whereas Japan's use of aid to remove restrictive fishing regulations worked well in the early 1980s through essentially lop-sided bilateral agreements with Pacific island nations, the balance of power changed in the late 1980s. Japan faces an increasingly united independent Oceania from this time and significant competition from other players willing to sign more balanced fishing deals. Circumstances particularly changed in favour of island nations after the US signed a multilateral access agreement with Pacific nations [24] (p. 96).

The sea out of sight of land within and beyond Pacific island nations' EEZs remains beyond the control of the state. These areas beyond the shoreline horizon are the aquatic equivalent to Burton's terra nugax - resource rich areas on land that are often lightly populated or harvested by relatively few people, so that local inhabitants have little political influence in national parliaments and other decision-making bodies, which are invariably based in national capitals. The seas of the Pacific are the aquatic equivalent - mare nugax, especially as their increasingly valued resources attract more and more commercial attention. Such circumstances can be seen as existing in high seas beyond EEZs and, indeed, over most parts of EEZs beyond site of land, given the scarce monitoring resources of Pacific island nations.

The consequences of these circumstances and potential solutions sought by Pacific island nations are discussed below in relation to the two most valuable offshore assets discovered so far in Oceania - tuna and seabed minerals. Such a comparison is rare, but vital, as the long data sets now accumulated on the increasingly under stress tuna fishery raise serious issues about the efficacy of the broadly similar multilateral de jure or de facto voluntary compliance regimes (in the absence of monitoring capacity) being set up to manage mining of the seabed.

\section{Preservation of the Western and Central Pacific Tuna Fishery}

The open ocean fisheries of Oceania are classic examples of the economic paradigm of the tragedy of the commons - the idea that there is a tendency towards unsustainable use of areas not owned by specific groups or individuals, but for which there is common access, either legally or de facto [29]. In such circumstances, no one group has a compelling interest to protect them if they are open to all comers, and so, they seek to maximize their return before the resource is exhausted. Such circumstances can be seen as existing in high seas beyond EEZs and, indeed, over most parts of EEZs beyond site of land, given the scarce monitoring resources of Pacific island nations. The Western and Central Pacific tuna fishery is particularly under stress from over-fishing, because of these circumstances, with the only current means of reversing this trend being voluntary conservation regimes seeking to persuade fishers that it is in their best long-term interests to comply.

The Western and Central Pacific tuna fishery is the largest and most intact tuna fishery in the world, supplying around half of the world's tuna supplies. It is also crucial to the nations it straddles, as their territorial sea to land ratio is up to 3,000 to one, and their land resources are scarce, as well as circumscribed. These nations lack the capital to develop their own domestic fleets and to maintain and run patrol vessels and, so, generally opt for renting out fishing rights within their EEZs to fleets from larger, wealthier Pacific Rim nations for, on average, only $3 \%-4 \%$ of the value of the catch landed. For example, in 1998, Pacific island nations received approximately 60 million USD in fishing access fees from fleets that declare an annual catch sale price of approximately 1.3-1.9 billion USD. Data from the Secretariat of the Pacific Community reveals that Oceanic nations' EEZs yield 78 
percent of the Western and Central Pacific Ocean tuna catch. The Oceanic artisanal catch represents less than 10 percent of the total catch in this fishery [12,30-34].

The wealth of the Western and Central Pacific tuna fishery relative to over-exploited and exhausted fisheries elsewhere has resulted in increased pressure on this fishery. The main species targeted in the Western and Central Pacific tuna fishery are skipjack tuna (Katsuwonus pelamis), yellowfin tuna (Thunnus albacares) and bigeye tuna (T. obesus) [30]. In the last decade, the Secretariat of the Pacific Community has declared bluefin tuna critically endangered and bigeye and yellowfin tuna to be in dramatic decline [35]. The reason is not hard to determine. The total harvest has increased by an average of $5 \%$ per year over the past 50 years. This average understates the escalating pressure the fishery is under given that the number of boat-days has risen about $10 \%$ per year over the period, 1970-2000 [36]. In addition to this, illegal, unreported and unregulated (IUU) fishing within this fishery is estimated to take between eight and 16 percent of the reported annual catch in the Asia-Pacific region [37,38]. The IUU fishing in Oceania takes the form of unlicensed vessels fishing within EEZs, fishing in closed areas or misreporting or under-reporting of catches [39]. The IUU fishing vessels have lower costs than licensed vessels, as they pay less or no fees and are not bound by national or regional fisheries requirements.

A variety of management principles and agreements have been applied to improve the health of the fishery and gain greater control and benefits for Pacific island nations. Pacific island nations have pooled their fisheries expertise for economies of scale to provide member nations with advice and information they could not have access to with their individual resources. These island nations have a regional scientific fisheries data collecting agency in Noumea, New Caledonia, within the Secretariat of the Pacific Community, and a managerial and advisory agency body, the Forum Fisheries Agency (FFA), in Honiara in the Solomon Islands. These pooled resources have their limits, though, in dealing with distant water fishing nations (DWFN) [40].

The United Nations Fish Stocks Agreement of 2001 sought to develop a regime for voluntary action by stakeholder nations to preserve global fisheries. The agreement was based around the principle that coastal nations containing harvestable fisheries and DWFN required cooperation to effectively manage fish stocks on a sustainable basis, either bilaterally or multilaterally, or through setting up Regional Fisheries Management Organisations (RFMOs). The 2004 Tuna Convention flowed on from this, but its poorly funded Fisheries Commission limited its regulatory capacity, with enforcement of guidelines for sustainable harvests left to flag states - that is, states the fishing vessels are registered in, but not necessarily resident in. This created an obvious distance from, and tension with, territorial states in which unsustainable harvests are made and was also impractical if the catch was sold in a port of a third state, especially one not party to a regional agreement. The Western and Central Pacific tuna fishery is collectively managed by member countries of the Western and Central Pacific Fisheries Commission (WCPFC). Members agree to adhere to a set of multilateral compliance measures, including compulsory registration of all fishing vessels, a vessel tracking system that plots the location of all registered fishing vessels and a scheme to record and cap the total number of vessel days in the fishery by purse seine vessels. None of these measures address the problem of IUU fishing, however [36,37].

Ten DWFN harvest 86 percent of the catch sold at market from the Pacific, especially Japan, Taiwan, South Korea and the United States. Despite that all major stakeholders bar Japan from signing a 
Multilateral High Level Convention (MHLC) on the Conservation and Management of Highly Migratory Fish Stocks in the Western and Central Pacific Ocean in Honolulu in 2000 [41], DWFN continue to prefer bilateral relations to multilateral ones when dealing with Pacific island nations [31,41,42]. The exception has been the United States, whose multilateral agreement with Pacific Forum nations produced terms more favourable to island nations than most bilateral ones with DWFN [43]. Bilateral agreements tend to be less restrictive on DWFN operations than protocols Pacific island nations collectively agreed to in the FFA. The latter are perceived as also potentially compromising bilateral aid, which is seen by DWFN donors as a potential tool for access to fishery rights on terms desired by them.

Many of the DWFN that signed MHLC 2000 have plans to develop canneries in the Pacific Marine Industrial Zone (PMIZ) in Madang, PNG. This a huge enterprise, which will eventually consist of 10 canneries processing the catch of many fleets fishing the Western and Central Pacific tuna fishery on a scale well in excess of FFA scientific models for sustainable catches for this fishery. PNG has its own fishing fleet and is a member of the FFA, but sees its best interests as lying in these collective bilateral arrangements. However, the PNG Government is out of kilter with the desires of its coastal dwelling citizens, who have consistently rejected large-scale foreign-owned developments on the coast as perilous to the local environment and economy. The traditional owners of the land the PMIZ is due to be built on oppose the scheme, but have been removed from their land without compensation by national laws that privilege government over local communities when national development schemes are agreed upon. Traditional maritime tenure and exploitation rights are even more tenuous under national legislation $[44,45]$.

Economists Chand, Grafton and Peterson argue that only multilateral agreements can provide the basic requirements for sustainable governance of the Western and Central Pacific tuna fishery [12]. These requirements are that: fishers were actively involved in co-management of resources; that total exploitation rates need to be accepted by most resource users and set at sustainable levels; fishers need both long-term interests in preserving the fishery and individual incentives to do so; and lastly, that as with all international agreements, all parties must voluntarily cooperate in joint management, abide by the rules of exploitation and support mechanisms to restrict new entrants into the fishery. They see the need for a single policy maker, such as a tuna commission, to set consistent and universally applied rules, to arbitrate disputes and support measures to restrict new entrants. Such an authority requires stakeholders to agree to give a percentage of their catch revenue to the authority to provide it with financial powers and capacity. In another paper on this fishery, Parris and Grafton note a tension between coastal nation national jurisdiction in EEZs and multilateral jurisdiction beyond EEZs in which coastal nations perceive little benefit to themselves from exploiting the high seas [46]. They suggest that such tension can be reduced by sharing any rise in sale price with Pacific nations as the USA agreed to, setting up Trust Funds for them from tuna sales to partly rectify the small 3\%-4\% of catch sale price they receive as a resource rent $[12,33,46]$.

There are a variety of other options. Fleets of the European Union (EU) pay an average access rent equating to $18 \%$ of the catch sale price to West African coastal nations (and up to $45 \%$ of the catch sale price in some cases), which if applied to the 1998 figures for Oceania cited above would mean a leap from 60 million USD in access fees to 270 million USD. As the world's fisheries diminish, the bargaining position of Pacific island nations should increase to enable the negotiation of similar rates to those occurring in the more exhausted Atlantic fishery. Setting aside a percentage of this increased 
revenue for monitoring and policing could raise income and protect the fishery by countering the huge trade in unreported and illegal fishing that floats unknown on top of the official sale price and catch figures. Kompas et al. argue that if the amount of tuna landed were to be reduced and if stocks were to rise due to reduced fishing, then profits (but not necessarily total revenues) would increase, because tuna would be easier and cheaper to catch [36]. Carrying on with the same levels of exploitation will soon lead to massive financial losses as the cost of locating and landing increasingly scarce tuna outweigh increased sale price, due to scarcity. In other words, at lower rates of exploitation, Pacific island nations and DWFN would, overall, make more money [36,37,47].

\section{Sovereignty and Access Issues Surrounding Seabed Mining}

The oceans' benthic (seabed) environments remain some of the least known ecosystems on Earth, despite the fact that most of the Earth's geological surface is seabed. In July 2011, slowly accumulating evidence of the economic potential of the ocean floor was given a boost when Japanese scientists published evidence of large deposits of rare-earth metals on the seabed in the eastern South Pacific and central North Pacific [48]. Rare-earth metals are among the most expensive minerals on Earth, because of the general lack of terrestrial sources concentrated enough to be commercially viable to mine. There have been significant advances in seabed technology in recent years for exploring and mining at great depths [49]. Other types of mineral deposits are also claimed to be approaching viable levels for seabed mining, although these claims are by no means uncontested, as discussed below.

A recently discovered rare-earths' deposit between 3 and 5-6 km deep off Japan is reportedly 1,000-times larger than any on land [49]. Rare-earths is the collective name for 17 oxidized minerals vital to modern computer and green technology, such as wind turbines and fuel efficient cars. The battery of a Toyota Primus, for example, has more than 20 pounds of the rare-earth element, Lanthanum (element 57 on the element table), while magnets on large wind turbines may contain 500 pounds of neodymium (element 60 ). Rare-earths are not so much rare and rarely concentrated in sufficient amounts to be commercially exploitable. The timing of the offshore discovery was fortuitous for Japan, as in 2010, China, which supplies $97 \%$ of the world's rare-earth needs, cut shipments to Japan for a month over a heated dispute between the two nations over ownership of the Senkaku/Diaoyu Islands. The Chinese burgeoning economy already absorbs up $60 \%$ of the Chinese rare-earth production, prompting fears that it may soon reduce exports to build up its own reserves. As world demand approached supply, the Chinese measures against Japan in 2010 prompted a surge in the price of rare-earths, with the price of Cerium (Element 58), for example, increasing $450 \%$ in 2010 alone. The Pacific seabed discoveries of rare-earths published in the journal Nature Geoscience in July, 2011, were found to be so rich, that according to one of the investigating team members, Yasuhiro Kato, an Associate Professor of Earth Science at the University of Tokyo, "The deposits have a heavy concentration of rare-earths. Just one square kilometre ( 0.4 square mile) of deposits will be able to provide one-fifth of the current global annual consumption [48,50-52]".

This new maritime frontier looks set to expand in the near future. The Canadian mining company, Nautilus Minerals, has announced advanced preparations to commence large-scale deep sea mining operations for copper and gold in PNG in 2013, and the United Nations' designated regulator of seabed mining beyond EEZs, the International Seabed Authority (ISA), is processing a small, but rising number of applications for seabed mineral exploration in the Pacific. While Nautilus's 
operations in PNG have been delayed, the delay centres on a legal dispute with the host government over cost sharing arrangements rather than issues of technical or economic viability [53] (p. 6). The rapidity of progress towards commercial seabed mining commencing has left national governments and international regulators scrambling to design and put in place policies, safeguards and laws pertaining to seabed minerals within and beyond EEZs [48-51]. These new economic opportunities may also pose a potential threat of unknown magnitude to Pacific fisheries and may require greater coordination between fisheries and seabed mining regulators and industries in years to come.

There are three types of known seabed mineral deposits. The main Pacific locations of each type of deposit are illustrated in Figure 1 below. The first consists of manganese nodule, which are fist-sized polymetallic clumps containing valuable minerals, such as manganese, nickel, copper and cobalt, that lie on the seabed. Most known deposits lie in the deep ocean in international waters as deep as 5,000 meters or three miles down. Most known deposits are in the central Pacific and, also, to a lesser extent, in the Indian Ocean. The concentrations with the most commercial potential in the Pacific are located at depths of 4,500 to 5,500 meters in the Clarion Clipperton area of the central eastern Pacific. Manganese nodules are considered to be commercially viable if they have an average nickel and copper content of $2.25 \%$ or more and a nodule density of around 10 kilograms per square metre. Analysis of nodules in the Clarion Clipperton area suggests that this area alone contains twice the amount of cobalt contained in total land-based reserves [54-57]. Although their existence has been known for over 100 years, technical difficulties with extraction, legal uncertainty about access and ownership rights to seabed mine sites and the cost of extraction relative to land-based deposits deterred seabed mining. Sustainability may also be an issue once more data on their abundance is known, as nodules take millennia to reach their modest size. Improvements in technology derived from offshore oil and gas operations have now made the extraction of this type of mineral technically feasible. The second type of potentially commercially viable seabed mineral deposit is cobalt-rich crusts on ridges and seamounts in all the world oceans [58].

Figure 1. Pacific seabed mineral locations.

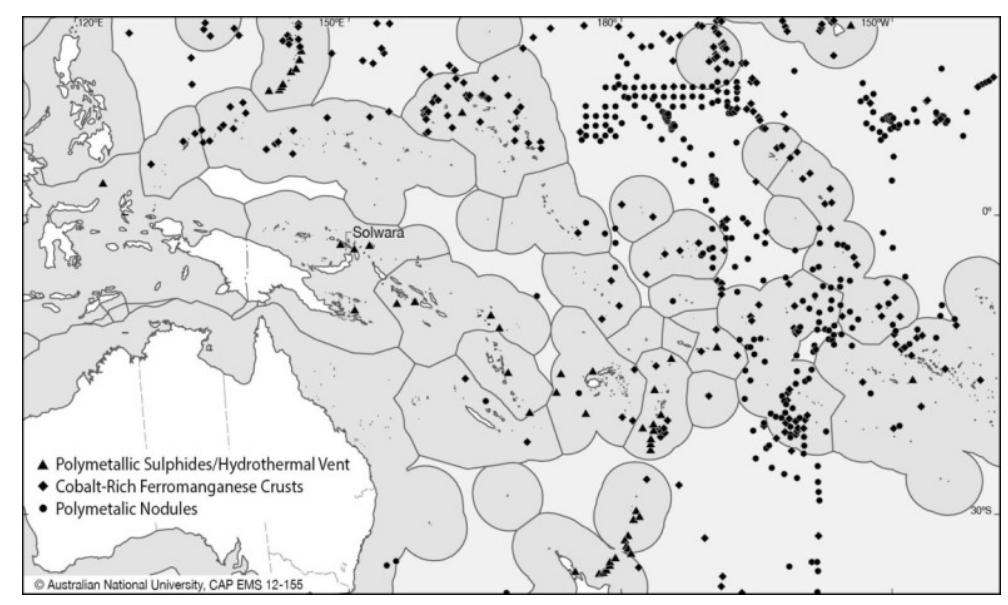

The third type of seabed mineral deposit is polymetallic sulphides formed around hot springs in volcanic areas where seawater heated by hot rock as it seeps into volcanic fissures dissolves minerals and, then, rises like a geyser from the seabed to cool and condense the minerals. These deposits can be up to seven-times the quality of the same mineral mined on land and can grow up to six meters per 
year. These vents abound along the Western Pacific's Rim of Fire. Most of those discovered so far lie within EEZ with many in water as shallow as 1-2 km, and they have already attracted bids for exploration licenses off New Zealand, Japan, Fiji, Tonga, Solomon Islands and PNG. To date, around 200 vent fields have been located, although most appear too small to be viable to mine $[59,60]$. The Pacific's first significant seabed mining operation being developed by Nautilus Minerals in PNG targets one of these types of deposits.

Exploration has revealed a consistent pattern of vent fields occurring at 100 kilometre intervals, which would equate to 600 fields emitting minerals of varying amounts along the Pacific's mid-ocean ridge alone. Nautilus Minerals estimates that if just 50 percent of these fields prove to be commercially viable, this would represent several billion tonnes of copper per annum [54]. Its first seabed mine volcanic vent site in PNG, the 0.112 square kilometre Solwara 1, is considered commercially viable, as its copper deposits are ten times more concentrated than most copper deposits mined on land. Prior to its legal dispute with the PNG Government, Joe Dowling, Vice President of Investor Relations for Nautilus Minerals, expected Solwara I to be in production by the end of 2013 and to generate ca. 80,000 tonnes of copper and 150,000 ounces of gold per year. Nautilus's exploratory investigations at Solwara and other sites in the Bismarck Sea have led them to estimate that the site could yield 1.5 million tonnes of ore with copper and gold content per year. If Nautilus reports on the Solwara site, which is $50 \mathrm{~km}$ north of New Britain and $30 \mathrm{~km}$ west of New Ireland at 1,600 meters depth, are representative, then this load will yield 7\% copper and six grams of gold per tonne of ore extracted-well beyond the minimum concentration designated as profitable in these circumstances and much higher than the $0.5 \%$ some terrestrial mines operate at. While Nautilus has committed up to 80 million USD from 2005 until January, 2011, on exploration projects for its PNG venture and has been in negotiation with the PNG Government for over a decade on its proposed seabed mining operations, the accuracy of its estimates will only be revealed when Solwara commences operations [49,54,61-64].

A number of seabed mining specialists within the scientific community remain cautious about claims over seabed mining's economic and environmental feasibility. The economic viability argument for seabed mining is based on the assumption that the Earth's terrestrial mineral deposits are diminishing and that desired minerals will therefore increase in price as they become rare to the extent that the elevated price will compensate for the added costs of seabed mining compared to land-based mining. However, it has been noted that many land-based mines operate below full extraction capacity and large finds of valued minerals have been made on land in recent decades, such as the huge Grasberg deposit in 1988 in the vicinity of the long exploited Ertsberg mine in Indonesian New Guinea and Canada's largest ever large copper, cobalt and nickel deposit at Voisey's Bay in Newfoundland in 1994. Demand also generates recycling, conservation and technical advances to make extraction of lower grade sources viable. The extremely high and rising prices of rare-earths are unusual. For much of the 1980s and 1990s, world mineral prices were generally low. Those cautious about the economic benefits of seabed mining also note that mineral prices should lower as more minerals are extracted from the seabed, thereby eroding the very pricing mechanism that would make seabed mining economically viable. Claims about the technical viability of seabed mining are also untested in full-scale commercial operations. Critics concede that volcanic vent deposits in relatively shallow waters within EEZs are the best option for testing the technical viability of commercial seabed mining, but note that the extraction of manganese nodules and seacrust deposits in deeper waters has not been 
really investigated to the degree needed for commercial operators to commit significant funds to commence serious preparatory operations. In such circumstances, seabed mining and exploration would only be viable with government subsidies based on strategic reasons rather than economic reasons. It is argued that many of the seabed mining ventures in the Pacific in the past and today are driven by strategic, rather than economic considerations. The Chinese previously mentioned withholding of rare-earth shipments to Japan during its dispute over the Senkaku/Diaoyu Islands reinforces the importance of such considerations [64-68].

Commercial commitment to projects is best reflected in the amount spent on them. Nautilus's announced expenditure of around 80 million to exploration in the Solwara project until January, 2011, averages just over 13 million per year for no return to date [53]. In its 2007 Annual Report, the company announced cash reserves of 310 million USD and annual exploration costs of 40,876,742 USD (or 7.75\% of cash reserves) for the year ending 31 December, 2007, compared to 3,280,937 USD in exploration costs for the year ending December 31, 2006. The vast majority of annual expenditure was spent on its PNG operations, however [63]. To put this in perspective, studies of seabed mining operations in the 1970s and 1980 s noted that mining companies only spent $5 \%-7 \%$ of their annual budget on seabed mining exploration and research and development, as evidence that these projects were more speculative than prioritized [64]. In other words, Nautilus is financially more committed to its seabed mining exploratory phase operations in the Pacific than earlier commercial operators.

Indigenous peoples in Oceania who face the prospect of seabed mining are generally reluctant to have this activity in their neighbourhoods, despite the potential prospects of financial wealth and employment arising from mining operations. While tests of seabed mining have been conducted to monitor environmental damage to mined areas, the silt plume drifts arising from them suggesting that damage was temporary and acceptable, there are no working operations to prove or disprove claims from all parties [54,55]. In the absence of conclusive data, the potential for irreversible ecological damage from seabed mining is a justified fear for Pacific communities that are largely reliant on subsistence activities partly supplemented by growing crops or harvesting fauna from sea and land for sale in the cash economy. The inter-connected nature of near-shore and offshore ecosystems still requires much research, but is beyond dispute, as are the unforeseen and dramatic reverberations that even a small alteration in ecosystems can have elsewhere in the system [69].

In 2008, a coalition representing coastal communities around the Bismarck-Solomon Sea sought a greater say in decisions on seabed mining for indigenous peoples and vowed not to support any such operation until solid evidence could be provided by companies or the PNG Government that seabed mining would not cause significant damage to coastal and marine ecosystems [70]. There is insufficient data to ascertain how unified coastal communities are on this issue, and PNG's legislative framework favours state control of the sea and does not recognize indigenous or local community maritime tenure. Strong cases for recognition of native title have been argued elsewhere in Oceania, in nations where local indigenous community rights and guardianship to the sea were much more disrupted by colonial conquest and involuntary alienation of coastal land [71-73].

Seabed mineral deposits may have other significant economic value, as well as minerals. No hydrothermal vent communities have been comprehensively biologically mapped, and some may contain species with potentially significant energy or medical applications to human societies. For example, the biochemical properties of organisms that can tolerate temperature extremes found in 
and around deep sea vents and that find sustenance in toxic fluids of the vents have great potential benefit for biotechnology industries. Enzymes from hydrothermal vent organisms are already being used in a variety of ways, such as skin lotion that counters damage from free radicals [74-77]. Hydrothermal vent biota are specialized to adapt to their unique habitats and are, therefore, highly vulnerable to disruption of these habitats, especially given that the surrounding seabed ecology is usually quite different [54]. It therefore follows that seabed mining for minerals may destroy flora and fauna that also have economic and medicinal value for humanity, most of it as yet unknown. Vents targeted for mineral extraction should ideally be thoroughly biologically mapped before the commencement of mining. Balancing the delay in securing mineral revenue from mining, while seabed communities are mapped, and the possible loss of revenue and medical cures from biological extraction present the designated regulators of the seabed within and beyond Pacific EEZs with yet another significant legal conundrum to deal with.

Solwara 1, the Pacific's first potential commercial seabed mining operation, has been approached cautiously. The PNG National Government has the legal right to sanction seabed mining and has given its approval for mining to commence with due respect to PNG's strict environmental protection standards, which reflect almost four decades of dealing with and learning from land-based mining operations and ecological disasters, such as the downstream toxic pollution from the Ok Tedi copper and goldmine. At a Deep Sea Mineral Project Workshop in June, 2011, Senior Technical Assistant Engineer with PNG's Minerals Resource Authority (MRA), Lyndah Brown-Kola, noted that PNG's lease agreement with Nautilus reflected the lessons of 36 years of developing legislation and regulatory frameworks for mining. She noted that this legislative and regulatory framework was administered by the MRA in conjunction with the Department of Mineral Policy and Geohazards Management. Government legislation also provides for PNG to acquire up to 30\% equity in mining operations in their country, and government policy is to provide a portion to the landowners as royalties through the government's independent commercial entity, Petromin. Brown-Kola noted that the license for seabed mining operations granted to Nautilus in 2008 only occurred at the end of a 14-year process of working with the company [78]. Scientific observers of the Solwara 1 site were impressed with Nautilus's protocols for protecting benthic biota in the exploratory stage of operations during their visit in 2006 [54].

Despite these lengthy negotiations, the untested nature of seabed mining and the limited research on seabed biological communities means that the environmental impact of seabed mining will only become apparent after mining commences. In such circumstances, the precautionary principle or precautionary approach should, and indeed must, prevail. This precautionary principle states that in the absence of scientific consensus on whether an action or policy will harm the public or the environment, the instigators must prove that it is not harmful before commencing. The precautionary approach offers more leeway for moving forward with caution than the precautionary principle, although both allow some leeway for new actions to be attempted with due consideration of safeguards as all the consequences of new actions cannot be known in advance [79,80]. These concepts have gained increasingly wider support since articulated as Principle 15 of the Rio Earth Summit Declaration in 1992. Principle 15 states "In order to protect the environment, the precautionary approach shall be widely applied by States according to their capabilities. Where there are threats of serious or irreversible damage, lack of full scientific certainty shall not be used as a reason for 
postponing cost-effective measures to prevent environmental degradation" [81]. In the case of seabed mining in unexplored or underexplored benthic biological communities, this might take the form of intensive biological surveys before the commencement of seabed mining and, also, beginning operations with a period of less intensive mining on one, preferably discrete section of a larger ecosystem to monitor the impact of mining and have an ecological reserve in case of unanticipated devastation. The appropriate length and form of such an experimental stage of mining would involve balancing marine science and commercial imperatives.

The final determinant of decisions to mine the seabed is perhaps the most problematic-security of ownership and/or user or extraction rights of the seabed, especially for deep seas beyond national EEZs. The determination of such rights is still being worked out within EEZs and, beyond national EEZs, remains confined to the granting of rights to explore for minerals in geographical zones applied for by mining companies, increasingly with the support of one or more national governments. The final UNCLOS set up the International Seabed Authority (ISA) in 1994 to regulate deep sea mining ventures outside nations' EEZs [82]. All 159 signatories to UNCLOS and the European Community are members of the ISA. The ISA's two representative bodies are the ISA Assembly on which all members sit and the 36-member Council elected by the Assembly on the basis of criteria designed to ensure equitable representation for various groups, including those engaged in seabed mineral exploration (four members); land-based producers of minerals found on the seabed (four members); developing nation states with special interests, such as those with large populations, land-locked nations, island states and states that are potential land-based producers of seabed minerals or major importers of minerals to come from the sea beds to be mined (six members); and geographical coverage of the globe, with at least one member from each of the following regions: Africa, Asia, Eastern Europe, Latin America and the Caribbean, Western Europe and others. Membership is rotated by vote on a four-year cycle and is held by representatives of nation-states. At present, Fiji is the only Pacific island member of the ISA Council [82-84]. Assumptions that seabed mining beyond EEZs is only a distant possibility at present mean that the Authority currently only holds one annual session and has a modest budget of only 6.5 million USD and 35 staff members [54,82].

Legislation pertaining to Pacific island national EEZs also remains embryonic, but momentum is gathering, as more and more companies seek access and preparations for seabed mining operations to commence. The EU is currently sponsoring a four-year project to help Pacific Forum nations to develop their seabed mining policy frameworks [85,86]. In 2008, private companies in Tonga and Nauru aligned with the Canadian company, Nautilus Minerals, and supported by their governments, became the first developing nation entities to apply for ISA authorization to explore the seabed beyond EEZs for polymetallic nodules. The ISA granted an exploration contract to Nauru Ocean Resources Inc. in July, 2011, and to Tonga Offshore Mining Limited in January, 2012 [19,87].

\section{Conclusion: Towards a Comprehensive Approach to Marine Resource Management}

Pacific island nations face major challenges in seeking multilateral solutions to oceanic issues confronting them. Their collective thinking is reflected in the Pacific Islands Regional Ocean Policy (PIROP) produced by a Marine Sector Working Group of the Council of Regional Organisations in the Pacific in response to a request from Pacific Island Forum leaders in 1999. The PIROP seeks to "ensure the future sustainable use of our ocean and its resources by Pacific islands' communities and 
external partners" [88]. The PIROP outlined five guiding principles for ensuring this objective: improving understanding of the ocean; sustainable development and management of ocean resources; maintaining the health of the ocean; promoting the peaceful use of the ocean; and creating partnerships and promoting cooperation.

Within these broad global concerns, more Oceania-specific principles were emphasized, such as the importance of protecting traditional knowledge of the sea and the implied intrinsic value of such knowledge alongside and in partnership with Western marine scientific knowledge. PIROP was endorsed by Pacific island leaders and expected to serve as the foundation for the development of national ocean policies, as well as enhanced regional guardianship of the Pacific [88]. The first major follow up meeting after the PIROP was launched was the Pacific Islands Regional Oceans Forum held in Fiji in 2004, with discussion centering on how to convert the principles into implementable actions nationally and regionally. Regional support for the 2000 WCPFC and PIROP made Oceanic nations world leaders in the development of regional collaborative initiatives to protect and sustain what Laurence Cordonnery rightly labels "the largest and last commercially sustainable ocean on Earth" [31] (p. 731).

There is mounting evidence that a three-tier scheme combining local community near-shore management, with national and regional frameworks, combining indigenous, national, scientific and commercial interests, may be the best and, indeed, only way to preserve and regulate Oceania's marine resources. The wealth of most near-shore fisheries, especially the highly productive reef and lagoon complexes surrounding many islands, meant that fishing activities and tenure units were generally much more concentrated than elsewhere in the world. The incomplete nature of European conquest and consolidation in the Pacific islands meant that indigenous tenure and use of the sea continued in varying degrees alongside the rules and practices of the new colonizers. Historical and anthropological research has revealed that coastal Pacific Islanders controlled and exploited a wide variety of inshore and blue water ecosystems. Results varied. Their most enduring and successful systems of fisheries management have been highly localized operations, where communities reliant on harvesting the sea also regulate its use $[33,34,71,89]$. Much of Oceania's commercially harvested fisheries fall within the territorial waters of Pacific island nations. While concerns have already been raised about the depletion of certain species of tuna in offshore waters by unmonitored multinational fleets, islanders still retain control of near-shore waters upon which much of the offshore fishery is built.

The Pacific 2020 Background Paper: Fisheries recommends improving coastal fisheries management through community involvement [90]. As well as monetary benefits, local participation in inshore harvesting provides protein sources, import substitution for costly processed foods and local management of marine areas. Kiribati is developing a variety of initiatives to expand its near-shore resource base. These include tapping into the specialist aquarium fish market and seaweed and pearl farming [22] (pp. 9-14). Grafton et al. are more specific, pointing out that such schemes are particularly effective if local communities have the incentive to effectively manage the resource through uncontested ownership and receiving benefits from the harvest of the resource [91]. Management is most effective when there are group rights that lead to collective community action [91,92].

Local community control of local near-shore fisheries, as practiced by Pacific Islanders, has also worked well as a conservation and management principle in parts of the Pacific Rim not controlled by indigenous peoples, such as Japan. Pacific island and Pacific Rim marine management systems represent a wide variety of workable schemes and contexts that are all concerned with disputed near-shore access 
rights. Comparative studies of such disputes and their resolution are needed to broaden awareness of options and put local disputes into context. A series of local regimes and interest groups can and do operate under a broad umbrella of national or international principles, such as conservation of endangered ecosystems and species being paramount over sector or community interests, and open, but differentiated, access to the foreshore on the basis of historical and cultural factors [92-96].

Such a comprehensive approach is vital, as epitomized by the two case studies detailed above, in which seabed minerals and the tuna fishery in the waters above the seabed are dealt with as separate legal entities covered by different authorities under UNCLOS and migratory tuna are covered by different provisions in different locations along their routes. The new economic opportunities offered by seabed mining may also pose a potential threat of unknown magnitude to Pacific fisheries and may require greater coordination between fisheries and seabed mining regulators and industries in years to come.

Cordonnery ends his insightful commentary on the practicality of implementing the PIROP by noting its two major challenges — one within Oceania and one concerning DWFN. "Within the region, political leadership and the willingness to commit and raise adequate resources will be essential if the foreseeable implementation difficulties outlined in this article are to be overcome. This challenge will determine whether the Policy can be used as a model in ocean governance as it promises to be. For regional powers within the Pacific Rim who were not part of the inception and endorsement phases of the PIROP process, their commitment to PIROP will be determined by Pacific Rim nations' willingness to act as partners and to cooperate with PICs in the implementation process" [31](p. 731).

Eventual multilateral, international legal agreements on Pacific fisheries and seabed mining should not be seen as inevitable, if somewhat distant from realization. Pacific nations may start seeing merit in emphasizing bilateral relations if multilateral fishing agreements continue to be violated or they have a limited say in decision making processes concerning seabed mining. The FSM is currently in discussion with the PRC concerning exclusive rights to fish in its EEZ, which gives the PRC a stake in also policing illegal fishing within a zone of exclusiveness that the host nation lacks the resources to police and monitor itself. Tonga's and Nauru's alliance with the commercial mining company, Nautilus, to secure a stake in the resource extraction and in the ISA organizational process has been noted [87].

Faced with the possibility of a profusion of fragmented and uncoordinated arrangements with various commercial operators and external nation states, Pacific island nations need to develop common policies that view the range of Pacific marine resources as an integrated and interrelated whole. Fisheries legislation and institutions are far ahead of those for seabed minerals in this regard. Variable levels of research and legislation on different marine resources open the risk of a variety of narrowly focused marine policies inadvertently counteracting each other. Seabed mining will most likely first proceed within Pacific nation EEZs, allowing greater Pacific island control of the process. This also means that Pacific island pelagic, benthic and neritic environments will bear the brunt of any negative consequences of seabed mining. Wilkinson and Salvat recently made a strong case that phenomenon associated with the tragedy of the commons had now extended to populated coastal areas of the Pacific and elsewhere, adding an extra moral dimension to an environmental problem [97]. They argue that the solution to the declining circumstances of those now suffering from this phenomenon lies in humanity as a whole making moral choices about lifestyle decisions, such as population policy and material lifestyles [97]. 
There are, therefore, very real limits to the empowerment of Pacific island states in managing Pacific Ocean maritime resources. The destinies of both Pacific island MIRAB economies and resource rent economies in this era of heightened, human-induced climate change are now even further linked to processes beyond its area over which they have no influence. The low lying atolls of the Pacific are particularly prone to sea level rise and increased typhoon activity and intensity associated with global warming [98]. Now, more aware of influences looming just over the horizon, the region's inhabitants must, nevertheless, still generally modify the impact of these external forces rather than hope to shape them. However, Pacific island nations can exercise much greater control than they do at present through utilizing working and enduring models of local management and working collaboratively with each other, with marine scientists and commercial entities to anticipate future trends in marine resource use further offshore.

\section{Conflict of Interest}

The author declares no conflict of interest.

\section{References and Notes}

1. Firth, S. Sovereignty and Independence in the Contemporary Pacific. TCP 1989, 1, 75-96.

2. Pacific tells EU - conclude EPA or we're out. Available online: http://www.islandsbusiness.com/ news/fiji/1424/pacific-tells-eu-conclude-epa-or-were-out/ (accessed on 14 May 2013).

3. Nero, K. The Material World Remade. In The Cambridge History of the Pacific Islanders; Denoon, D., Ed.; Cambridge University Press: Cambridge, UK, 1997; pp. 359-396.

4. Bertram, G.; Watters, R. The MIRAB Economy in South Pacific Microstates. Pac. View. 1985, 26, 497-519.

5. Bertram, G. The MIRAB model twelve years on. TCP 1999, 22, 105-138.

6. Hau'ofa, E. Our sea of islands. TCP 1994, 6, 148-161.

7. D'Arcy, P. Cultural divisions and island environments since the time of Dumont d'Urville. J. Pac. Hist. 2003, 38, 217-236.

8. Allen, M. Greed and grievance: The role of economic agendas in the conflict in Solomon Islands. Pac. Econ. Bull. 2005, 20, 56-71.

9. Banks, G. Mining and the environment in Melanesia: Contemporary debates reviewed. TCP 2002, 14, 39-67.

10. Kabutaulaka, T.T. Rumble in the jungle: Land, culture and (un) sustainable logging in the Solomon Islands. In Culture and Sustainable Development in the Pacific; Hooper, A., Ed.; Asia Pacific Press: Canberra, Australia, 2000; pp. 88-97.

11. Doulman, D.J., Ed. Tuna Issues and Perspectives in the Pacific Islands Region; East-West Center: Honolulu, HI, USA, 1987.

12. Chand, S.; Grafton, R.Q.; Petersen, E. Multilateral governance of fisheries: management and cooperation in the Western and Central Pacific tuna fisheries. Mar. Resour. Econ. 2003, 18, 329-348.

13. Filer, C.; Macintyre, M. Grass roots and deep holes: Community responses to mining in Melanesia. TCP 2006, 18, 215-231. 
14. Scheyvens, R.; Lagisa, L. Women, disempowerment and resistance: An analysis of logging and mining activities in the Pacific. J. Trop. Geog. 1998, 19, 51-71.

15. Burton, J. Terra nugax and the discovery paradigm: How Ok Tedi was shaped by the way it was found and how the rise of political process in the North Fly took the company by surprise. In The Ok Tedi Settlement: Issues, Outcomes and Implications; Glenn, B., Chris, B., Eds.; National Centre for Development Studies: Canberra, Australia, 1997; pp.27-55.

16. United Nations. The Law of the Sea: Exclusive Economic Zone, Legislative History of Articles 56, 58 and 59 of the United Nations Convention on the Law of the Sea. Available online: http:// www.un.org/Depts/los/convention_agreements/texts/unclos/closindx.htm (accessed on 14 May 2013).

17. Brownlie, I., Ed. Basic Documents in International Law, 4th ed.; Oxford University Press: Oxford, UK, 1995; pp. 87-208.

18. Harris, D.J. Cases and Materials on International Law, 6th ed.; Sweet and Maxwell: London, UK, 2004; pp. 381-503.

19. International Seabed Authority. Available online: http://www.isa.org.jm/files/images/ CCZ_contractors-resize2.jpg (accessed on 14 May 2013).

20. Crocombe, R. The South Pacific; University of the South Pacific: Suva, Fiji, 2001; pp. 309-310.

21. Gupta, D.; Yala, C. Fishing, Forestry and Mining. In The Pacific Islands: An encyclopedia; Lal, B.V., Fortune, K., Eds.; The University of Hawaii Press: Honolulu, HI, USA, 2000; pp. 366-371.

22. Thomas, F.R. Fisheries development in Kiribati: Sustainability issues in a "MIRAB" economy. Pac. Stud. 2003, 26, 1-36.

23. Teiwaki, R. Management of Marine Resources in Kiribati; University of the South Pacific: Suva, Fiji, 1988.

24. Tarte, S. Japan's Aid Diplomacy and the Pacific Islands; National Centre for Development Studies: Canberra, Australia, 1998; p. 83.

25. Lobban, C.S.; Schefter, M. Tropical Pacific Island Environments; University of Guam Press: Hagåtña, Guam, 1997; pp. 274-277.

26. Bardach, J.E.; Ridings, P.J. Pacific Tuna: Biology, Economics, and Politics. In Ocean Yearbook, 5th ed.; Borgese, E.M., Ginsburg, N., Eds.; University of Chicago Press: Chicago, IL, USA, 1985; pp. 29-57.

27. Jacobs, M. Spoiled Tuna: A Fishing Industry Gone Bad; Micronesian Seminar: Pohnpei, Federated States of Micronesia, 2002; pp. 1-15.

28. Gillett, R. Traditional Tuna Fishing: A study at Satawal, Central Caroline Islands; Bernice P. Bishop Museum: Honolulu, HI, USA, 1987; p.1.

29. Hardin, G. The Tragedy of the commons. Science 1968, 162, 1243-1248.

30. Williams, P.; Reid, C. Overview of the Western and Central Pacific Ocean (WCPO) Tuna Fisheries, including Economic Conditions-2005. Available online: http://www.wcpfc.int (accessed on 14 May 2013).

31. Cordonnery, L. Implementing the Pacific Islands Regional Ocean Policy: How difficult is it going to be? VUW. Law. Rev. 2005, 36, 723-731.

32. Gillett, R.; Rodwell, M.L.; Tamate, J. Tuna: A Key Economic Resource in the Pacific: A Report prepared for the Asian Development Bank and Forum Fisheries Agency; Asian Development Bank: Manila, Philippines, 2001. 
33. D'Arcy, P. The role of the tuna fishery in the economy of Federated States of Micronesia. Pac. Econ. Bull. 2006, 21, 75-87.

34. D'Arcy, P. The People of the Sea: Environment, Identity, and History in Oceania; University of Hawaii Press: Honolulu, HI, USA, 2006.

35. Forum Fisheries Agency (FFA). Proposed Outline of Regional MCS Strategy Projects and Strategy: Development of an Integrated Regional MCS Strategy; FFA: Honiara, Solomon Islands, 2008.

36. Kompas, T.; Grafton, Q.R.; Che, T.N. Bioeconomic losses from overharvesting tuna. Conserv. Lett. 2010, 1-7.

37. Food and Agriculture Organization of the United Nations (FAO). International Plan of Action, to Prevent, Deter, and Eliminate Illegal, Unreported and Unregulated Fishing. Available online: http://www.fao.org/fi/website/FIRetrieveAction.do?dom=topic\&fid-16007 (accessed on 14 May 2013).

38. Marine Resources and Fisheries Consultants (MRAG) and University of British Columbia (UBC). The Global Extent of Illegal Fishing. Available online: http://www.Illegalfishing.info/uploads/MRAGExtentGlobalIllegalFishing.pdf (accessed on 14 May 2013).

39. Marine Resources and Fisheries Consultants (MRAG). Review of Impacts of Illegal, Unreported and Unregulated Fishing on Developing Countries, Synthesis Report. Available online: http:// www.imcsnet.org/imcs/imcs/docs/iuu_fishig_synthesis_report_mrag.pdf(accessed on 14 May 2013).

40. D'Arcy, P. Oceania: The environmental history of one third of the globe. In A Companion to Global Environmental History; McNeill, J.R., Stewart, E.C., Eds.; Wiley Blackwell: Oxford, UK, 2012; pp. 196-221.

41. Multilateral High Level Convention (MHLC). Report of the Eleventh and Final Session of the Multilateral High Level Conference on the Conservation and Management of Highly Migratory Fish Stocks in the Western and Central Pacific; MHLC: Honolulu, HI, USA, 2000.

42. Tarte, S. Negotiating a Tuna management regime for the Western and Central Pacific: The MHLC process 1994-1999. J. Pac. Hist. 1999, 34, 273-280.

43. Van Dyke, J.; Nicol, C.U.S. Tuna Policy: A reluctant acceptance of the international norm. In Tuna Issues and Perspectives in the Pacific Islands Region; Doulman, D.J., Ed.; East-West Center: Honolulu, HI, USA, 1987; pp. 105-132.

44. Matbob, P. PMIZ Project Development Proceeds. Available online: http://www.islandsbusiness.com/ islands_business/index_dynamic/containerNameToReplace=MiddleMiddle/focusModuleID=18845/ overideSkinName=issueArticle-full.tpl (accessed on 14 May 2013).

45. Sullivan, N. The Sullivan Report. Available online: http://www.rdtunapng.com/docs/ sullivan report.htm (accessed on 14 May 2013).

46. Parris, H.; Grafton, R.Q. Can tuna promote sustainable development in the Pacific? J. Environ. Dev. 2006, 15, 269-296.

47. Bertignac, M.; Campbell, H.F.; Hampton, J.; Hand, A.J. Maximizing resource rent in the Western and Central Pacific tuna fisheries. Mar. Resour. Econ. 2000, 15, 151-177.

48. Kato, Y.; Fujinaga, K.; Nakamura, K.; Takaya, Y.; Kitamura, K.; Ohta, J.; Toda, R.; Nakashima, T.; Iwamori, H. Deep-sea mud in the Pacific Ocean as a potential resource for rare-earth elements. Nat. Geosci. 2011, 4, 535-539. 
49. Latimer, C. Seabed Mining: Plunging into the depths of a new frontier. Available online: http://www.miningaustralia.com.au/news/seabed-mining-plunging-into-the-depths-of-a-new-frontier (accessed on 14 May 2013).

50. Arthur, C. Japan discovers 'rare earth' minerals used for iPads. Available online: http://www.guardian.co.uk/technology/2011/jul/04/japan-ipads-rare-earth (accessed on 14 May 2013).

51. Kurien, D. Rare earth minerals are found on Pacific Ocean Floor. Available online: http://online.wsj.com/article/SB10001424052702304760604576425230759407002.html (accessed on 14 May 2013).

52. Folger, T. The secret (Chinese) ingredient of (almost) everything. Nat. Geog. Mag. 2011, 219, $136-145$.

53. Consolidated Financial Statements For the years ended December 31, 2012 and December 31, 2011. Available online: http://www.nautilusminerals.com/i/pdf/2012-Q4-FS.pdf (accessed on 14 May 2013).

54. Drew, L.W. The Promise and Perils of Seafloor Mining. Available online: https://www.whoi.edu/cms/files/PromiseAndPeril_68263.pdf (accessed on 14 May 2013).

55. Markussen, J.M. Deep seabed mining and the environment: consequences, perceptions, and regulations. In Green Globe Yearbook of International Co-operation on Environment and Development; Helge, O.B., Georg, P., Eds.; Oxford University Press: Oxford, UK, 1994; pp. 31-39.

56. Cronan, D.S. Manganese nodules. In Encyclopedia of Ocean Sciences; Steele, J., Turekian, K., Thorpe, S., Eds.; Academic Press: San Diego, CA, USA, 2001; pp. 1526-1533.

57. International Seabed Authority: Polymetallic Nodules. Available online: http://www.isa.org.jm/ files/documents/EN/Brochures/ENG7.pdf (accessed on 14 May 2013).

58. International Seabed Authority: Cobalt-rich Crusts. Available online: http://www.isa.org.jm/files/ documents/EN/Brochures/ENG9.pdf (accessed on 1 August 2013).

59. International Seabed Authority: Polymetallic Suplphides. Available online http://www.isa.org.jm/ files/documents/EN/Brochures/ENG8.pdf (accessed on 14 May 2013).

60. Seabed mining: The unplumbed riches of the deep. Available online: http://www.economist. com.node/13649273 (accessed on 14 May 2013).

61. Shwartz, M. Mining the world's richest copper resource-On the seabed. Available online: http://www.theajmonline.com.au/pdfs/nov-dec-2010/ajm-nd-p8-9.pdf (accessed on 14 May 2013).

62. Nautilus: US\$80mil spent on Solwara 1. Available online: http://www.islandsbusiness.com/ news/papua-new-guinea/1372/nautilus-us80mil-spent-on-solwara-1/ (accessed on 14 May 2013).

63. A new vision in mining. Available online: http://www.nautilusminerals.com/i/pdf/2007AR.pdf (accessed on 14 May 2013).

64. Glasby, G.P. Deep Seabed Mining: Past Failures and Future Prospects. Mar. Georesour. Geotec. 2002, 20, 161-176.

65. Silver, D.B. The quest for lower costs is killing metal prices. Geotimes 2001, 46, 34-35.

66. Skinner, B.J. Perspectives for mineral exploration in the 21st century. Episodes 2001, 24, 6.

67. Chung, J.S.; Schreiver, G.; Sharma, R.; Yamazaki, T. Deep seabed mining environment: Preliminary engineering and environmental assessment. In Proceedings of the Fourth (2001) Ocean Mining Symposium, Szczecin, Poland, 23-27 September 2001; pp. 8-13. 
68. Ham, K.S. A study on economics of development of deep-seabed manganese nodules. In Proceedings of the Second Ocean Mining Symposium, Seoul, Korea, 24-26 November 1997; pp. 105-111.

69. Sharp, G.D. Fish populations and fisheries: Their perturbations, natural and man-induced. In Ecosystems of the World 27: Continental Shelves; Postma, H., Zijlstra, J.J., Eds.; Elsevier: Amsterdam, The Netherlands, 1988; pp. 155-202.

70. Karkum National Sea Bed Mining Forum Statement: June 25-27th, 2008. Available online: http://seaturtles.org/article.php?id=1124 (accessed on 14 May 2013).

71. Bambridge, T., Ed. The Rahui: Legal Pluralism, Environment, and Land and Marine Tenure in Polynesia; ANUE Press: Canberra, Australia, 2013; in press.

72. Ruru, J. What could have been: The common law doctrine of native title in land under water in Australia and Aotearoa/New Zealand. Monash University Law Review 2006, 32, 116-144.

73. Van Dyke, J. The role of indigenous peoples in ocean governance. Available online: http://www.unu.edu/unupress/unupbooks/uu15oe/uu15oe09.htm\#the\%20role\%20of\%20indigenou s\%20peoples\%20in\%20ocean\%20governance (accessed on 14 May 2013).

74. Ocean bugs used in sun lotions. Available online: http://news.bbc.co.uk/2/hi/health/1628324.stm (accessed on 14 May 2013).

75. Copley, J. Some like it hot. Available online: http://www.newscientist.com/article/ dn1503-deepsea-bugs-produce-super-sunscreen.html\#.UcKmQEX5fVI (accessed on 14 May 2013).

76. Henne, A.; Brüggemann, H.; Raasch, C.; Wiezer, A.; Hartsch, T.; Liesegang, H.; Johann, A.; Lienard, T.; Gohl, O.; Martinez-Arias, R.; et al. The genome sequence of the extreme thermophile Thermus thermophilu. Nat. Biotechnol. 2004, 22, 547-553.

77. An Extreme Thermophile, Thermus thermophilus, is a Polyploid Bacterium. Available online: http://jb.asm.org/content/192/20/5499.full.pdf (accessed on 14 May 2013).

78. Papua New Guinea Ready for Seabed Mining. Available online: http://www.sopac.org/index.php/ media-releases/1-latest-news/299-papua-new-guinea-ready-for-seabed-mining (accessed on 14 May 2013).

79. Kriebel, D.; Tickner, J.; Epstein, P.; Lemons, J.; Levins, R.; Loechler, E.L.; Quinn, M.; Rudel, R.; Schettler, T.; Stoto, M. The precautionary principle in environmental science. Environ. Health Persp. 2001, 109, 871-876.

80. Lauck, T.; Clark, C.W.; Mangel, M.; Munro, G.A. Implementing the precautionary principle in fisheries management through marine reserves. Ecol. Appl. 1998, 8, 572-578.

81. United Nations Conference on Environment and Development. Available online: http://www.unep.org/Documents.multilingual/Default.asp?DocumentID=78\&ArticleID=1163 (accessed on 14 May 2013).

82. International Seabed Authority. Available online: http://www.isa.org.jm/files/documents/EN/ Brochures/ENG1.pdf (accessed on 14 May 2013).

83. International Seabed Authority: The Council. Available online: http://www.isa.org.jm/en/about/ members/council (accessed on 14 May 2013).

84. International Seabed Authority: Composition of the Council. Available online: http:// www.isa.org.jm/en/about/members/council/composition (accessed on 14 May 2013). 
85. Radio Australia. Help for Pacific countries seabed mining development. Available online: http://www.radioaustralia.net.au/pacbeat/stories/201102/s3148747.htm (accessed on 14 May 2013).

86. Radio Australia. Samoa moves on seabed mining. Available online: http://www.radioaustralia.net.au/ pacbeat/stories/201106/s3257291.htm (accessed on 14 May 2013).

87. Papua New Guinea Mine Watch. International Seabed Authority approves seabed exploration in Nauru and Tonga. Available online: http://ramumine.wordpress.com/2011/08/04/ international-seabed-authority-approves-seabed-exploration-in-nauru-and-tonga/ (accessed on 14 May 2013).

88. Pacific Islands Forum Secretariat. Available online: http://www.spc.int (accessed on 14 May 2013).

89. Anderson, A., Ed. Traditional Fishing in the Pacific; Bernice P. Bishop Museum: Honolulu, HI, USA, 1986.

90. Clark, L. Pacific 2020 Background Paper: Fisheries; Commonwealth of Australia: Canberra, Australia, 2006.

91. Grafton, R.Q.; Arnason, R.; Bjørndal, T.; Campbell, D.; Campbell, H.F.; Clark, C.W.; Connor, R.; Dupont, D.P.; Hannesson, R.; Hilborn, R.; et al. Incentive-based approaches to sustainable fisheries. Can. J. Fish. Aquat. Sci. 2006, 63, 699-710.

92. Hviding, E.; Baines, G.B.K. Community-based fisheries management: Tradition and the challenges of development in Marovo, Solomon Islands. Dev. Change 1994, 25, 13-39.

93. Johannes, R.E.; Macfarlane, J.W. Assessing customary marine tenure systems in the context of marine resource management: A torres strait example. In Traditional Marine Resource Management in the Pacific Basin: An Anthology; Ruddle, K., Johannes, R.E., Eds.; UNESCO: Jakarta, Indonesian, 1990.

94. Laffoley, D.; White, A.T.; Kilarski, S.; Gleason, M.; Smith, S.; Llewellyn, G.; Day, J.; Hillary, A.; Wedell, V.; Pee, D.; et al. Establishing Resilient Marine Protected Area Networks-Making It Happen; International Union for Conservation of Nature World Commission on Protected Areas (IUCN-WCPA): Washington, DC, USA, 2008.

95. Govan, H. Status and Potential of Locally-Managed Marine Areas in the South Pacific: Meeting Nature Conservation and Sustainable Livelihood Targets through Wide-Spread Implementation of LMMAs; Coral Reef Initiatives for the Pacific (CRISP): Noumea, France, 2009.

96. Veitayaki, J.; Nakoro, A.D.R.; Sigarua, T.; Bulai, N. On cultural factors and marine managed areas in Fiji. In Pacific Island Heritage: Archaeology, Identity and Community; Liston, J., Clark, G., Alexander, D., Eds.; ANU E Press: Canberra, Australia, 2011; pp.37-49.

97. Wilkinson, C.; Salvat, B. Coastal resource degradation in the tropics: Does the tragedy of the commons apply for coral reefs, Mangrove forests and seagrass beds. Mar. Pollut. Bull. 2012, 64, 1096-1105.

98. Mortreux, C.; Barnett, J. Climate change, migration and adaptation in Funafuti, Tuvalu. Global Environ. Change 2009, 19, 105-112.

(C) 2013 by the authors; licensee MDPI, Basel, Switzerland. This article is an open access article distributed under the terms and conditions of the Creative Commons Attribution license (http://creativecommons.org/licenses/by/3.0/). 